\title{
THE PROBLEM OF ENVIRONMENTAL POLLUTION IN THE MEDITERRANEAN SEA ALONG THE COAST OF TURKEY
}

\author{
MUHAMMED ERNUR AKINER ${ }^{1 *}$ \\ ${ }^{1}$ Akdeniz University, Vocational School of Technical Sciences, Environmental Protection \\ and Control, Antalya, Turkey
}

\begin{abstract}
Turkish coastline neighbor to the Mediterranean Sea faces serious problems such as eutrophication and diffuse pollution. Among diffuse pollution, the leading actor is intensive agriculture. This research focuses on four developed cities, Antalya, Mersin, Adana, and Hatay, along the Turkish Mediterranean shoreline. The inadequate sewage system and insufficient treatment plants lead to eutrophication in populated cities. In the year 2017, in Turkey's Mediterranean region, Aksu, Manavgat, Göksu, Seyhan, Ceyhan, and Asi rivers were monitored. Concentration values for $\mathrm{BOD}_{5}$, Total Phosphorus, Nitrite Nitrogen, and Nitrate Nitrogen parameters were determined. This study observes the pollution status of the rivers according to the Turkish Water Pollution Control Regulation. One sample T-Test determined the actual pollution potentials of the rivers. Besides, uncontrolled heavy metal and toxic emissions from industry are essential problems.
\end{abstract}

Keywords: agriculture, the Mediterranean Sea, environmental, eutrophication, diffuse pollution, nutrients

\section{INTRODUCTION}

The Mediterranean Sea is under thread of wastewater discharges from municipalities, industries, rivers. Another threat is the oil seep, which is common in Hatay due to petroleum transport and ship maintenance [1].

This research underlines the level of pollution and recommends necessary measurements that could be taken against pollution on the Mediterranean Sea along Turkey's shoreline. It is also to highlight the most critical issues related to pollution in the Mediterranean Sea. The leading transboundary problems of the Mediterranean Sea are nutrient-enrichment/eutrophication, changes in marine living resources, diffuse pollution, and biodiversity/habitat changes [2]. Diffuse pollution involves actual diffuse pollution and a large number of contaminated dispersed, usually single, minor, spot sources [3]. Unfortunately, the population is concentrated parallel to the shoreline. Hence, pollution arises along the coastline [4]. It is challenging to establish an infrastructure suitable for such a quick urbanized city. Municipal and industrial wastewaters are often combined and discharged directly into the Mediterranean Sea.

Besides, current treatment practices in the heavy industry are generally inadequate. About 360 tons of solid waste is disposed of daily in Turkey's Mediterranean region [5]. Mixed wastes from municipality, industry, hospital, and other hazardous wastes are discharged to the closest rivers or directly into the Mediterranean Sea [6]. Solid wastes have to be classified and discarded by their characteristics [7]. Landfills are intended only for non-hazardous waste, and they should not accept hazardous, inert wastes. Furthermore, all emerging waste should be treated before being discharged to the landfills, according to the EU Water Framework Directive [8]. However, irregular discharge through the coastline is usual in Turkey's Mediterranean Sea region [6].

\footnotetext{
* Corresponding author, email: ernur.akiner@akdeniz.edu.tr

(C) 2020 Alma Mater Publishing House
} 
Figure 1 shows the investigated locations on the Turkish Mediterranean Sea Coast. Municipal infrastructure in Turkey is still unfavorable; hence this situation affects pollution in the Mediterranean Sea in terms of nutrient pollution. Besides, heavy metals, organic pesticides, and incidental spills from oil vessels and ports are other pressures on the Mediterranean Sea.

Nutrient pollution leads to depletion of oxygen, which allows the habitat to survive in the receiving water environment [9]. In this sense, the most crucial aim of the research is to determine and reveal the actual nutrient pollution by using statistical methods.

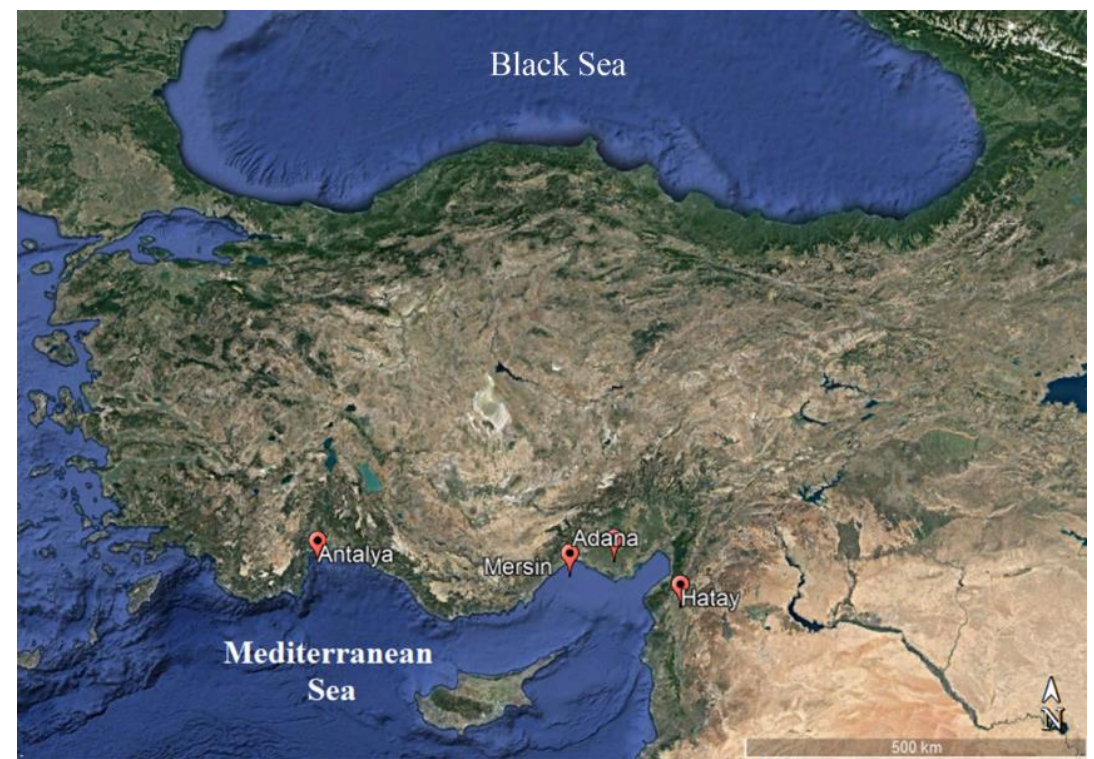

Fig. 1. Provinces (Antalya, Mersin, Adana, and Hatay) in the Mediterranean Sea coast of Turkey [10].

\section{METHODOLOGY}

In this study, the water quality classification of the Aksu, Manavgat, Göksu, Ceyhan, Seyhan, and Asi Rivers from 2017 to 2018 was determined according to the Surface Water Quality Management Regulation (SWQMR) of Turkey [11]. The Aksu and Manavgat Rivers are located in Antalya, the Göksu River in Mersin, the Seyhan and Ceyhan Rivers in Adana, and the Asi River in Hatay.

Primary river pollution comes from municipal, agricultural, air, and heavy industry. Main rivers form the

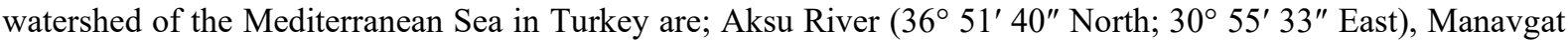

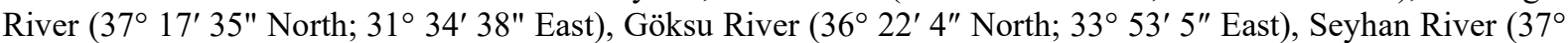

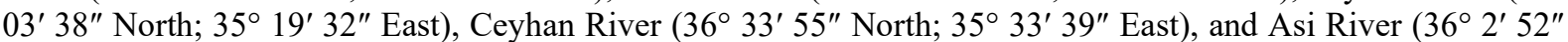
North; 35०58' 1" East) (Figure 2).

Water quality data were gathered through both field experiments and the environmental status reports of provinces where all rivers are located [12-15]. BOD 5 , Total Phosphorus, Nitrite Nitrogen, and Nitrate Nitrogen parameters were observed since mainly the agricultural industry induces them.

The high amount of phosphorus and nitrogen leads to a frequently seen problem called eutrophication. Nutrient concentration highly blooms waterbody, and oxygen is rapidly depleted in the case of eutrophication [16, 17]. Aquatic ecosystems are disrupted by overfed if nitrogen, phosphorus, and carbon compounds are in over-limit concentrations [18]. Mainly, the organic nutrient loads discharged into the receiving waters cause eutrophication. Eutrophication is also lethal for fish species due to its toxic effect and oxygen depletion in the case of algal blooms [19]. Hence, river pollution control in the Mediterranean Sea area of Turkey is crucial to prevent nutrient discharge into the sea. Direct discharges from large agricultural, municipal, and industrial plants to the Mediterranean Sea account for only about $5 \%$ of the nitrogen, and $10 \%$ of the phosphorus load drained to the 
Sea by rivers $[3,4]$. This situation allows us to see how low the point source pollution is concerning the nonpoint source pollution problem in the region. The fact that point source pollution is very low compared to diffuse pollution is also an indication that the lack of drainage, piping, and infrastructure is at dangerous levels. The sizeable agricultural production in the region and the increasing population due to tourism activities are the main issues related to the high nutrient loads in the rivers.

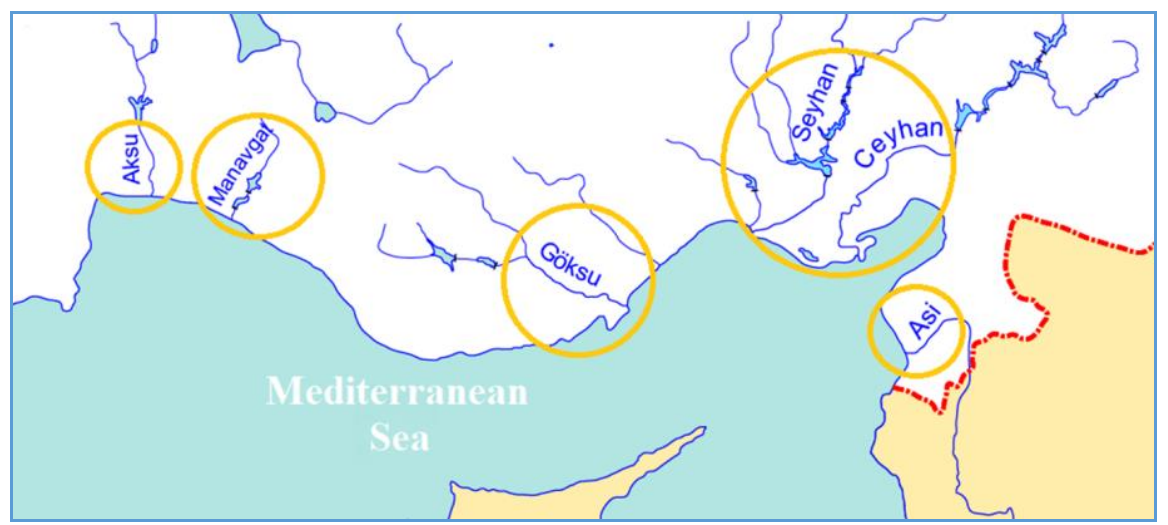

Fig. 2. Main rivers in the region that flow into the Mediterranean Sea.

\section{RESULTS AND DISCUSSION}

Table 1 shows the Surface Water Quality Management Regulation (SWQMR) of Turkey [11]. SWQMR is a regulation to determine all aspects of water pollution control, river, lake, and groundwater quality, protection zones for water reservoirs, discharge principles, domestic and industrial wastewater discharge standards. Inland waters categorized as Class I: high-quality waters, Class II: light-polluted waters, Class III: polluted waters, and Class IV: classified as seriously polluted waters [11]. Concentration values for pollution parameters were collected for Antalya, Mersin, Adana and Hatay.

Table 1. Water quality classes, according to the Surface Water Quality Management Regulations (SWQMR) of

\begin{tabular}{lllll}
\hline \multicolumn{5}{c}{ Turkey [11]. } \\
\hline Parameter & 1 & \multicolumn{5}{c}{ Water Quality Class } \\
\hline BOD $_{5}(\mathrm{mg} / \mathrm{L})$ & $<4$ & 2 & 3 & 4 \\
Total Phosphorus (mg/L) & $<0.02$ & $<8$ & $<20$ & $>20$ \\
Nitrite Nitrogen (mg/L) & $<0.002$ & $<0.16$ & $<0.65$ & $>0.65$ \\
Nitrate Nitrogen (mg/L) & $<5$ & $<10$ & $<0.05$ & $>0.05$ \\
\hline
\end{tabular}

Human activities strongly influence the nitrogen and phosphorus content of many rivers [20, 21]. Traditional agriculture is also considered to be an essential source of nitrogen and phosphorus [22, 23]. Hence to constrain pesticide usage is only possible by the use of best management practices. Organic agriculture should be taken on the agenda while preparing the development plans for the Mediterranean Sea region.

The Seyhan, Ceyhan, and Asi rivers are sources of pesticides because it lies in the southeast part of the Mediterranean Region. The drainage area of the region in southern Turkey consists of fertile plains [24-26]. Rivers like Aksu, Manavgat, and Göksu are located at the southwest Mediterranean Sea coast, and their drainage area influenced by regions in Central Anatolia where agriculture is extensive [27-29]. All streams are laid in the industrial activity region. Pesticide usage is high along with the toxic chemical pollution due to industries [30].

Considering the density of the industries in the region, and the lack of infrastructure, the existence of toxic pollution is an indisputable fact. Toxic pollution exerted from industrial facilities adversely influences the Mediterranean Sea. The chromium, lignite, iron, sulfur, and bauxite industry are the principal industrial polluters in the region. Adana is one of the developed provinces of the region. The sector in Adana has many branches such as; iron, glass, cement, weaving, food, chemical, agricultural vehicles, metalware, brick, and tobacco. 
Mersin, which is located in the Mediterranean region, is a developed port city. There is an Ataş oil refinery in Mersin.

In Antalya, ferrochrome manufacturing and oil factories are located. Heavy metal pollution due to the iron and steel industry and the oil spill problem in ports is the most critical environmental problems observed in Hatay [31,32]. Heavy metal emission is the leading environmental issue of the marine environment [33]. Oil spills and seeps are other frequently seen diffuse pollution. Treatment plants must be modernized and their number should be increased.

Today biological treatment is applied in all cities mentioned in this research. However, the population of these touristic cities is doubling, tripling in summers. Pretreatment is applied during peak times as a wastewater treatment process. Marine disposal follows processes such as screening, primary sedimentation, and grid removal.

The infrastructure consists of the combined sewer system for whole cities. The Provincial Bank of Turkey announced that the treatment plants are essential. Besides, the Environment and Forestry Ministry of Turkey has issued many regulations for wastewater treatment according to the EU membership accession. Metal manufacturing is, unfortunately, the conventional industrial sources of environmental contamination. Heavy metals are a carcinogen, and they are accumulated in a variety of aquatic organisms [34-36]. At high concentrations, heavy metals are toxic chemicals. Moreover, at low levels, heavy metals exist as micronutrients [37].

One sample T-Test statistical test was implemented to categorize river water quality. The available pollution data is continuous and also distributed normally; therefore, the One-Sample T-Test is applicable. The mean observed values were already compared with the permitted values given by SWQMR to assess the pollution status. However, a more precise analysis requires the statistical test that is conducted to decide the real pollution status. Hence, the One-Sample T-Test results were applied to the gathered pollution data, and the results are shown in Table 2 - 5 .

Table 2. One-Sample T-Test results for the observed river $\mathrm{BOD}_{5}$ pollution data.

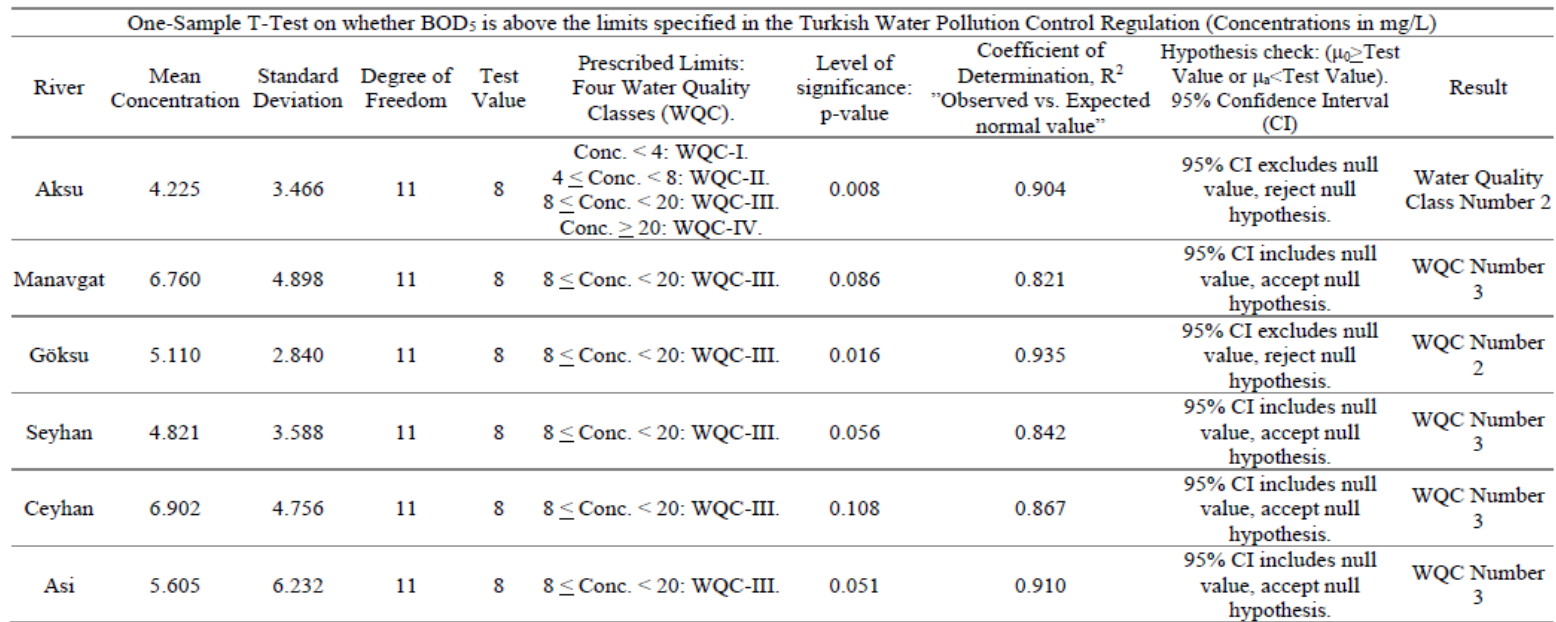

Table 2 shows that Manavgat, Seyhan, Ceyhan, and Asi rivers are potentially in much worse status than what is appeared in terms of oxygen deprivation. When the average $\mathrm{BOD}_{5}$ concentrations are considered, although they have $2^{\text {nd }}$ class water according to Turkish regulation, statistical analysis reveals that these rivers have the potential of $3^{\text {rd }}$ class water quality which is a lower level in terms of oxygen deprivation. Similarly, Table 3 shows the same situation for the Aksu, Manavgat, Seyhan and Ceyhan rivers considering the total phosphorus concentration. In terms of Nitrite Nitrogen concentrations, Aksu, Manavgat, Göksu, Ceyhan, and Asi rivers have a much higher potential (Table 4). When the Nitrate Nitrogen pollution is examined, it has been found that the pollution potential is higher especially in Manavgat, Seyhan and Ceyhan Rivers which are used in agricultural irrigation (Table 5). 
Table 3. One-Sample T-Test results for the observed river Total $\mathrm{P}$ pollution data.

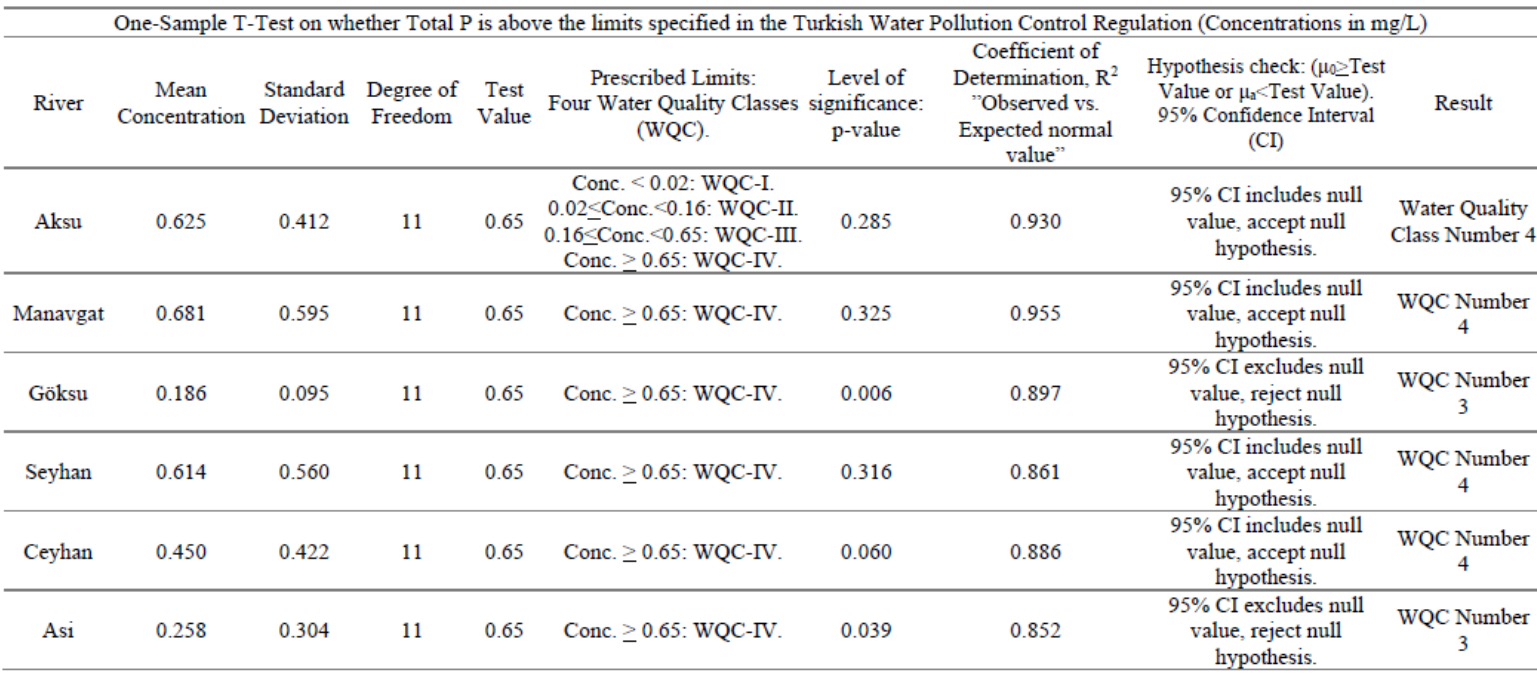

Table 4. One-Sample T-Test results for the observed river $\mathrm{NO}_{2}-\mathrm{N}$ pollution data.

\begin{tabular}{|c|c|c|c|c|c|c|c|c|c|}
\hline \multicolumn{10}{|c|}{ One-Sample T-Test on whether $\mathrm{NO}_{2}-\mathrm{N}$ is above the limits specified in the Turkish Water Pollution Control Regulation (Concentrations in $\mathrm{mg} / \mathrm{L}$ ) } \\
\hline River & $\begin{array}{c}\text { Mean } \\
\text { Concentration }\end{array}$ & $\begin{array}{l}\text { Standard } \\
\text { Deviation }\end{array}$ & $\begin{array}{l}\text { Degree of } \\
\text { Freedom }\end{array}$ & $\begin{array}{l}\text { Test } \\
\text { Value }\end{array}$ & $\begin{array}{c}\text { Prescribed Limits: } \\
\text { Four Water Quality Classes } \\
\text { (WQC). }\end{array}$ & $\begin{array}{l}\text { Level of } \\
\text { significance: } \\
\text { p-value }\end{array}$ & $\begin{array}{c}\text { Coefficient of } \\
\text { Determination, } \mathrm{R}^{2} \\
\text { "Observed vs. } \\
\text { Expected normal } \\
\text { value" } \\
\end{array}$ & $\begin{array}{c}\text { Hypothesis check: ( } \mu_{0} \geq \text { Test } \\
\text { Value or } \mu_{\mathrm{a}}<\text { Test Value). } \\
95 \% \text { Confidence Interval } \\
\text { (CI) }\end{array}$ & Result \\
\hline Aksu & 0.038 & 0.023 & 11 & 0.05 & $\begin{array}{c}\text { Conc. }<0.002: \text { WQC-I. } \\
0.002 \leq \text { Conc }<0.01: \text { WQC-II. } \\
0.01 \leq \text { Conc }<0.05: \text { WQC-III. } \\
\text { Conc. } \geq 0.05: \text { WQC-IV. }\end{array}$ & 0.053 & 0.832 & $\begin{array}{c}95 \% \text { CI includes null } \\
\text { value, accept null } \\
\text { hypothesis. }\end{array}$ & $\begin{array}{c}\text { Water Quality } \\
\text { Class Number } 4\end{array}$ \\
\hline Manavgat & 0.045 & 0.041 & 11 & 0.05 & Conc $\geq 0.05:$ WQC-IV. & 0.373 & 0.826 & $\begin{array}{l}95 \% \text { CI includes null } \\
\text { value, accept null } \\
\text { hypothesis. }\end{array}$ & $\begin{array}{c}\text { WQC Number } \\
4\end{array}$ \\
\hline Göksu & 0.037 & 0.021 & 11 & 0.05 & Conc. $\geq 0.05:$ WQC-IV. & 0.079 & 0.891 & $\begin{array}{l}95 \% \text { CI includes null } \\
\text { value, accept null } \\
\text { hypothesis. }\end{array}$ & $\begin{array}{c}\text { WQC Number } \\
4\end{array}$ \\
\hline Seyhan & 0.022 & 0.017 & 11 & 0.05 & Conc $\geq 0.05:$ WQC-IV. & 0.037 & 0.914 & $\begin{array}{l}95 \% \text { CI excludes null } \\
\text { value, reject null } \\
\text { hypothesis. }\end{array}$ & $\begin{array}{c}\text { WQC Number } \\
3\end{array}$ \\
\hline Ceyhan & 0.035 & 0.026 & 11 & 0.05 & Conc $\geq 0.05:$ WQC-IV. & 0.071 & 0.843 & $\begin{array}{l}95 \% \text { CI includes null } \\
\text { value, accept null } \\
\text { hypothesis. }\end{array}$ & $\begin{array}{l}\text { WQC Number } \\
4\end{array}$ \\
\hline Asi & 0.512 & 1.465 & 11 & 0.05 & Conc $\geq 0.05:$ WQC-IV & 0.999 & 0.908 & $\begin{array}{l}95 \% \text { CI includes null } \\
\text { value, accept null } \\
\text { hypothesis. }\end{array}$ & $\begin{array}{c}\text { WQC Number } \\
4\end{array}$ \\
\hline
\end{tabular}

Table 5. One-Sample T-Test results for the observed river NO3-N pollution data.

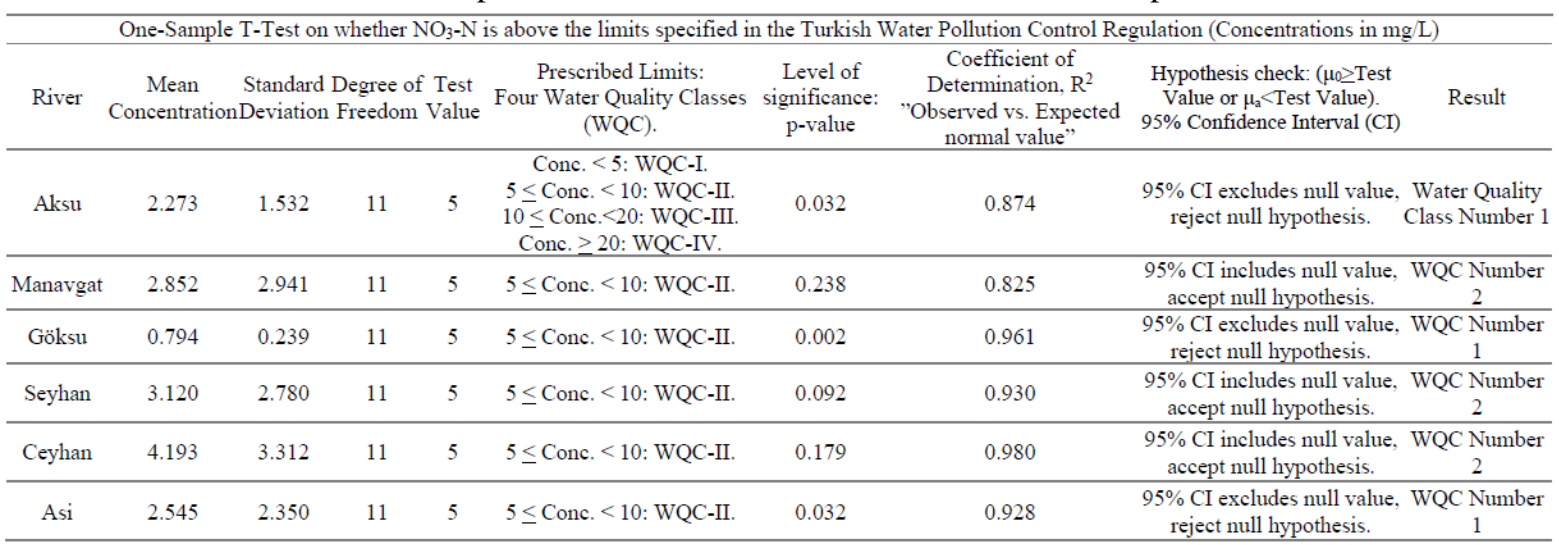




\section{CONCLUSIONS}

The main problem in the region is the diffuse pollution, which is mainly due to agriculture and industry. Organic farming should be in priority to get rid of pesticide and over usage of nutrients. The excess nutrient loading causes eutrophication. Agricultural best management practices should replace traditional farming practices.

Within this study, main rivers Aksu, Manavgat, Göksu, Seyhan, Ceyhan, and Asi were inspected since they are the most important ones among pollutant sources. Among the BOD 5 and Total P loading, the Seyhan and Ceyhan Rivers is the leading one that needs to be protected. Rivers' water quality can only be preserved using specific measures to improve water quality. The prior responsibility of the governors should be introducing an appropriate waste management system around the rivers. The results show that Antalya, Mersin, Adana, and Hatay provinces should rehabilitate their infrastructure systems and regulate municipal and industrial discharges and connect to treatment facilities appropriately.

Pesticides and fertilizers used in agricultural activities are the most critical chemical pollutants for water. The amount of fertilizer used in Antalya, Mersin, Adana, and Hatay provinces is several times the average of Turkey. The discharge of untreated wastewaters firstly leads to a decrease of dissolved oxygen (DO) levels in the Mediterranean Sea. Statistical analysis applied in this study categorized river water quality by Class I, II, III, and IV, according to the Turkish Water Pollution Control Regulation. These quality classes are high-quality waters, light-polluted waters, polluted waters, and seriously polluted waters, respectively.

Pollution in the Mediterranean also adversely affects habitat over time. Due to pollution, changes in the flow regimes in the water canals, and the physical formation of the Mediterranean Sea, species diversity in the habitat is gradually decreasing. Pollution prevention policies will help the protection of water quality in the Mediterranean Sea. Building the additional wastewater treatment plants and improvement of the existing treatment plants are crucial.

The most significant cause of nutrient pollution is the traditional agricultural practices, which are outdated. Rapidly environmentally friendly agrarian technologies should be expanded. With best management practices, the discharge of nutrients from agricultural lands to the receiving river should be avoided. Increasing tourism potential should be supported by effective treatment methods and facilities, and nutrient pollution should be prevented. Statistical analysis shows that average pollution concentrations are not sufficient to determine the pollution level in rivers. The fluctuating changes and seasonal fluctuations in pollution loads indicate that potential pollution is much higher.

\section{REFERENCES}

[1] European Environment Agency (EEA), Akdeniz bölgesi öncelikli çevre sorunları [Priority environmental problems in Mediterranean Region], Office of Official Publications of the European Communities, ISBN:97892-9167-370-4, 2006. http://www. eea.europa.eu/tr/publications/ eea_report_2006_4 (18.01.2020).

[2] Kostianoy, A.G., Carpenter, A., History, sources and volumes of oil pollution in the Mediterranean Sea In: Oil Pollution in the Mediterranean Sea: Part I, Springer, Cham, 2018, p. 9-31.

[3] UNEP/MAP, Barcelona Convention - Mediterranean 2017 quality status report land and sea-based pollution: common indicator 19 etc, Conclusions (CI19), 2017. https://www.medqsr.org/conclusions-ci19 (18.01.2020).

[4] UNEP/MAP, Barcelona Convention - Mediterranean 2017 quality status report. Results and Status, including trends (CI19), 2017. https://www.medqsr.org/results-and-status-including-trends-ci19 (18.01.2020).

[5] Carpenter, A., Kostianoy, A.G., Conclusions for Part II: National case studies in: oil pollution in the Mediterranean Sea: Part II, Springer, Cham, vol. 84, 2018. p. 263-285.

[6] UNEP/MAP, Marine Litter Assessment in the Mediterranean, ISBN No. 978-92807-3564-2, 2015.

[7] Indirapriyadharshini, U., Kumar, R.S., Venkatesan, S., Contemporary focuses on integrated solid waste management system through small-scale onsite composting for educational institution, in sustainable waste management: policies and case studies, Springer, Singapore, 2020, p. 233-246.

[8] Akıner, M.E., Investigating the effects of agricultural best management practices on water quality of a surface water, Zaštita Materijala, vol. 60, no. 4, 2019, p. 369-378.

[9] CEC, Council Directive 1999/31/EC of 26 April 1999 on the landfill of waste, Official Journal of the European Communities, vol 182, no. 1, 1999. 
[10] ESRI, Mediterranean Region - Turkey digital imaginary, satellite, and topographic map. DigitalGlobe, "GeoEye, i-cubed, USDA FSA, USGS, AEX, Getmapping, Aerogrid, IGN, IGP, Swisstopo, the GIS User Community, 2020. https://www.arcgis.com/home/webmap/viewer.html?webmap=a7df4341d88445fd80ca ff34d5c4c6fc\&extent=30.6138,36.8494,30.6363,36.8581 (18.01.2020)

[11] MFWA (Republic of Turkey Ministry of Forestry and Water Affairs), Surface water quality management regulation (SWQMR), Official Gazette (dated 30 November 2012, numbered 28483), Ankara, Turkey, 2012.

[12] Republic of Turkey Governorship of Antalya, Antalya Provincial Environmental Status Report 2017, Antalya, Turkey, 2018.

[13] Republic of Turkey Governorship of Mersin, Mersin Provincial Environmental Status Report 2017, Mersin, Turkey, 2018.

[14] Republic of Turkey Governorship of Adana, Adana Provincial Environmental Status Report 2017, Adana, Turkey, 2018.

[15] Republic of Turkey Governorship of Hatay, Hatay Provincial Environmental Status Report 2017, Hatay, Turkey, 2018.

[16] Rast, W., Thornton, J.A., The phosphorus loading concept and the OECD eutrophication programme: origin, application and capabilities. The Lakes Handbook., vol. 2, 2005, p. 354-385.

[17] Boynton, W.R., Ceballos, M.A.C., Bailey, E.M., Hodgkins, C.L.S., Humphrey, J.L., Testa, J.M., Oxygen and nutrient exchanges at the sediment-water interface: a global synthesis and critique of estuarine and coastal data, Estuaries and coasts, vol. 41, no. 2, 2018, p. 301-333.

[18] Bonanno, G., Orlando-Bonaca, M., Non-indigenous marine species in the Mediterranean Sea-Myth and reality, Environmental Science \& Policy, vol. 96, 2019, p. 123-131.

[19] El-Mezayen, M.M., Rueda-Roa, D.T., Essa, M.A., Muller-Karger, F.E., Elghobashy, A.E., Water quality observations in the marine aquaculture complex of the Deeba Triangle, Lake Manzala, Egyptian Mediterranean Coast, Environmental Monitoring and Assessment, vol. 190, no. 7, 2018, p. 436.

[20] Compa, M., Alomar, C., Wilcox, C., van Sebille, E., Lebreton, L., Hardesty, B.D., Deudero, S., Risk assessment of plastic pollution on marine diversity in the Mediterranean Sea, Science of The Total Environment, vol. 678, 2019, p. 188-196.

[21] Pasquier, V., Toucanne, S., Sansjofre, P., Dixit, Y., Revillon, S., Mokeddem, Z., Rabineau, M., Organic matter isotopes reveal enhanced rainfall activity in Northwestern Mediterranean borderland during warm substages of the last 200 kyr, Quaternary Science Reviews, vol. 205, 2019, p. 182-192.

[22] Republic of Turkey Ministry of Environment and Forestry (MEF), Su kirliliği kontrol yönetmeliği [Water pollution control regulation], Turkey: MEF. Report No.: 25687, 2004.

[23] Yates, G., Culp, J.M., Chambers, P.A., Estimating nutrient production from human activities in subcatchments of the Red River, Manitoba, Journal of Great Lakes Research, vol. 38, 2012, p. 106-114.

[24] Golge, M., Yenilmez, F., Aksoy, A., Development of pollution indices for the middle section of the Lower Seyhan Basin (Turkey), Ecological Indicators, vol. 29, 2013, p. 6-17.

[25] Aydin, I., Aydin, F., Hamamci, C., Phosphorus speciation in the surface sediment and river water from the Orontes (Asi) River, Turkey, Water Environment Research, vol. 82, no. 11, 2010, p. 2265-2271.

[26] Özbay, H., Yaprak, A.E., Turan, N., Assessing water quality in the Ceyhan River basin (Turkey) with the use of aquatic macrophytes, Chemistry and Ecology, vol. 35, no. 10, 2019, p. 891-902.

[27] Şener, Ş., Şener, E., Davraz, A., Evaluation of water quality using water quality index (WQI) method and GIS in Aksu River (SW-Turkey), Science of the Total Environment, vol. 584, 2017, p. 131-144.

[28] Cardak, M., Özbek, E.Ö., Kebapçioğlu, T., Seasonal abundance and diversity of culturable heterotrophic bacteria in relation to environmental factors in the Gulf of Antalya, Eastern Mediterranean, Turkey, World Journal of Microbiology and Biotechnology, vol. 31, no. 4, 2015, p. 569-582.

[29] Akiner, I., Akiner, E., Sustainable urban development: a case study on Goksu Delta, In Conf. on Water Observation and Information System for Decision Support, Ohrid, 2010.

[30] Özdilek, Ş.Y., Possible Threat for Middle East Inland Water: an Exotic and Invasive Species, Pterygoplichthys disjunctivus (Weber, 1991) in Asi River, Turkey (Pisces: Loricariidae), Su Ürünleri Dergisi, vol. 24, no. 3, 2007, p. 303-306.

[31] Yılmaz, A.B., Doğan, M., Heavy metals in water and in tissues of himri (Carasobarbus luteus) from Orontes (Asi) River, Turkey, Environmental monitoring and assessment, vol. 144, no. 1-3, 2008, p. 437-444.

[32] Gündoğdu, S., Çevik, C., Mediterranean dirty edge: High level of meso and macroplastics pollution on the Turkish coast, Environmental Pollution, vol. 255, no. 3, 2019, p. 1-9.

[33] Al Naggar, Y., Khalil, M.S., Ghorab, M.A., Environmental pollution by heavy metals in the aquatic ecosystems of Egypt, Open Access Journal of Toxicolgy, vol. 3, no. 1, 2018, p. 1-9. 
[34] Zaqoot, H.A., Aish, A.M., Wafi, H.N., Study on heavy metal pollution in Gaza fishing harbour along the Mediterranean Sea-Gaza beach, Palestine, Journal of Aquatic Science and Marine Biology, vol. 1, no. 1, 2018 , p. 24-34.

[35] Ashraf, S., Ali, Q., Zahir, Z.A., Ashraf, S., Asghar, H.N., Phytoremediation: environmentally sustainable way for reclamation of heavy metal polluted soils, Ecotoxicology and Environmental Safety, vol. 174, no. 1, 2019, p. 714-727.

[36] Bonanno, G., Orlando-Bonaca, M., Trace elements in Mediterranean seagrasses and macroalgae, A review, Science of the Total Environment, vol. 618, no. 1, 2018, p. 1152-1159.

[37] Prasad, M.N.V., Heavy metal stress in plants: from biomolecules to ecosystems, Ed. Springer Science \& Business Media, 2013. 